\title{
Assessment of the pathogenicity of bacterial species isolated from acute dentoalveolar abscesses
}

\author{
M. A. O. LEWIS, T. W. MACFARLANE, D. A. MCGOWAN* and D. G. MACDONALD \\ Department of Oral Medicine and Pathology and "Department of Oral Surgery, Glasgow Dental Hospital and \\ School, Glasgow G2 3JZ
}

\begin{abstract}
Summary. The pathogenicity of 20 strains belonging to nine bacterial species isolated from acute dentoalveolar abscesses was assessed individually and in two species combinations by subcutaneous inoculation of mice. Infections were produced by all the bacteria although variations were seen both in the type of lesion produced and the subsequent recovery of viable bacteria. Anaerobic gram-negative bacilli were recovered more often $(\mathrm{p}<0.05)$ at high concentrations $\left(10^{6}-10^{9} \mathrm{cfu} / \mathrm{ml}\right)$ and produced a localised abcess with peripheral necrosis more frequently $(p<0.001)$ than either Streptococcus milleri or anaerobic gram-positive cocci. Lesions induced by a combination of bacteria comprising an anaerobic gram-negative bacillus and any other species yielded both strains at high concentration more often $(p<0.001)$ than a combination comprising anaerobic gram-positive cocci and $S$. milleri. It is concluded that anaerobic gram-negative bacilli are major pathogens in acute dentoalveolar abscesses.
\end{abstract}

\section{Introduction}

Recent microbiological studies of acute dentoalveolar abscesses have demonstrated that the microflora is usually polymicrobial, consisting predominantly of anaerobic gram-negative bacilli and gram-positive cocci (Williams et al., 1983; Heimdahl et al., 1985; Lewis et al., 1986). It is uncertain, however, whether some isolates are more pathogenic than others because the bacterial species encountered are also members of the commensal oral microflora (Socransky, 1977; van der Velden et al., 1986). An association between the presence of gram-negative bacilli in acute dentoalveolar abscesses and an increased clinical severity (pain and fever) has recently been proposed (Heimdahl et al., 1985) but further information on the pathogenicity of the bacterial species involved is required to support this observation.

The pathogenic potential of bacterial species from subgingival plaque and necrotic dental pulps has been investigated in various animal models (MacDonald et al., 1963; Socransky and Gibbons, 1965; Takazoe and Nakamura, 1971; Sundqvist et al., 1979; van Steenbergen et al., 1982) but no information is available for micro-organisms cultured from acute dental abscesses (van Steenbergen

Received 11 Dec. 1987; revised version accepted 14 Mar. 1988. et al., 1984). Therefore, the aim of the present study was to investigate the capacity of bacterial species isolated from human acute dentoalveolar abscesses to induce subcutaneous tissue reactions in mice.

\section{Materials and methods}

\section{Bacterial species}

A total of 20 bacterial strains (table I) isolated from acute dentoalveolar abscesses were tested, either singly

Table I. Identity of 20 test organisms

\begin{tabular}{lc}
\hline \multicolumn{1}{c}{ Bacterial species } & $\begin{array}{c}\text { Number of } \\
\text { strains }\end{array}$ \\
\hline $\mathrm{CO}_{2}$-dependent gram-positive cocci & \\
$\quad$ Streptococcus milleri & 2 \\
Anaerobic gram-positive cocci & 3 \\
Peptococcus spp. & 1 \\
Peptostreptococcus spp. & \\
Anaerobic gram-negative bacilli & 2 \\
Bacteroides gingivalis & 2 \\
Bacteroides intermedius & 4 \\
Bacteroides melaninogenicus & 3 \\
Bacteroides oralis & Bacteroides ruminicola \\
Fusobacterium nucleatum & 1 \\
& 2 \\
\hline
\end{tabular}


or in two-strain combinations. The methods used during the original isolation and identification of the bacteria have been described previously (Lewis et al., 1986). All strains had been lyophilised since initial culture.

\section{Preparation of inocula}

Lyophilised cultures, reconstituted in Anaerobic Blood Broth (ABB) (Gibco), were grown on Columbia Blood Agar (Oxoid) for 5 days at $37^{\circ} \mathrm{C}$ in an anaerobic chamber (Don Whitley Scientific, Shipley, Yorkshire) in an atmosphere of $\mathrm{H}_{2} 10 \%, \mathrm{CO}_{2} 10 \%, \mathrm{~N}_{2} 80 \%$. Purity was checked and approximately 40 colonies were inoculated into $20 \mathrm{ml}$ of ABB which was incubated anaerobically at $37^{\circ} \mathrm{C}$ (facultative organisms for $24 \mathrm{~h}$, strict anaerobes for $48 \mathrm{~h}$ ). For some strains, especially anaerobic grampositive cocci, it was found that the concentration of the resultant culture was below that desired for the inoculum $\left(2 \times 10^{8} \mathrm{cfu} / \mathrm{ml}\right)$. Therefore, all broths were diluted with $\mathrm{ABB}$ to achieve a standard concentration of c. $2 \times$ $10^{7} \mathrm{cfu} / \mathrm{ml}$ estimated by spectrophotometry (Pye Unicam, Cambridge) with reference to previously determined growth absorbance curves. The suspensions were then concentrated by centrifugation at $3000 \mathrm{rpm}$ for $15 \mathrm{~min}$ and the bacterial pellet resuspended in one-tenth the volume of ABB. Inocula containing two bacterial species were prepared by mixing equal volumes of each broth culture at this stage.

Each suspension was then centrifuged at $3000 \mathrm{rpm}$ for $15 \mathrm{~min}$ and resuspended in an identical volume of ABB supplemented with agar (Gibco) $2 \% \mathrm{v} / \mathrm{v}$ maintained at $45^{\circ} \mathrm{C}$. This inoculum was then vortex-mixed for $30 \mathrm{~s}$. A $0.5-\mathrm{ml}$ volume of suspension was removed to determine bacterial viable count by serial dilution at 1 in 800,1 in 1600 and 1 in 16000 and inoculation on to Columbia Blood Agar with a spiral plater (Don Whitley Scientific). The remaining preparation was allowed to cool to room temperature and used as the inoculum within $1 \mathrm{~h}$. Sterile $\mathrm{ABB}$ containing agar $2 \% \mathrm{v} / \mathrm{v}$ was used as a control inoculum.

\section{Pathogenicity testing}

Male albino mice (BALB/c), weighing $22-26 \mathrm{~g}$, were lightly anaesthetised with ether. A $0 \cdot 2-\mathrm{ml}$ volume of each bacterial test suspension was inoculated subcutaneously in the right groin with a 1-ml disposable syringe fitted with a No. 18 microlance needle (Becton-Dickinson Ltd, Oxford). The mice were examined daily for evidence of swelling or ulceration at the site of inoculation and on the eighth day were killed by cervical dislocation.

The pathogenicity of nine bacterial species comprising 20 different bacterial strains was investigated in 81 mice and the pathogenicity of 11 combinations of two bacterial species in 55 mice.

\section{Microbiological assessment}

A 25- $\mu$ l sample of fluid was aspirated from the site of inoculation immediately after death with a microsyringe
(Burke Electronics Ltd, Glasgow). The syringe was washed out between animals with a $2 \%$ phenolic disinfectant (Sterling Industrial, Sheffield) and distilled water. A pilot study revealed that this procedure prevented carry-over of bacteria between samples without resulting in any reduction of viability of subsequent specimens. Samples were transported to the laboratory within $1 \mathrm{~h}$ for determination of viable counts.

\section{Histological assessment}

The right hind leg was dissected from the animal and placed in phosphate-buffered formalin $10 \%$ at $\mathrm{pH} 7$ for $72 \mathrm{~h}$. Paraffin-processed sections ( $5 \mu \mathrm{m}$ thick), stained with haematoxylin and eosin, were code numbered and examined randomly without details of the bacterial inoculum being known. Material from three tissue blocks of each animal was examined and, depending on the histological features, the lesions were allocated to one of three types of tissue reaction (A, B, and C) as described below (Results).

\section{Statistical analysis}

Fisher's exact probability test was used to determine the significance of any differences in the results.

\section{Results}

Injection of sterile medium into 10 control animals failed to produce any gross swelling at the site of inoculation. Histological examination of tissue from all the control animals demonstrated the suspending medium in the subcutaneous tissues surrounded by macrophages with minimal evidence of an acute inflammatory infiltrate (fig. 1). When the inoculum contained viable bacteria, three distinct tissue reactions developed: $A$, diffuse inflammatory infiltrate (fig. 2); B, localised abscess without peripheral necrosis (fig. 3); C, localised abscess with peripheral necrosis (fig. 4).

The bacterial strains were inoculated into groups of 3 or 4 mice. There were no marked differences in either the pattern of bacterial recovery or the tissue reaction produced between strains of the same species in single or double infections.

\section{Single strain experiments}

The recovery of bacteria from the inoculation site varied (table II). Viable bacteria were cultured from 19 animals at a low concentration $\left(10^{3} \mathrm{cfu} /\right.$ $\mathrm{ml}$ ) and from 38 animals at a high concentration $\left(10^{7}-10^{9} \mathrm{cfu} / \mathrm{ml}\right)$. No viable bacteria were cultured from 23 animals. Each bacterial strain tested was recovered from at least one mouse but Fusobacter- 


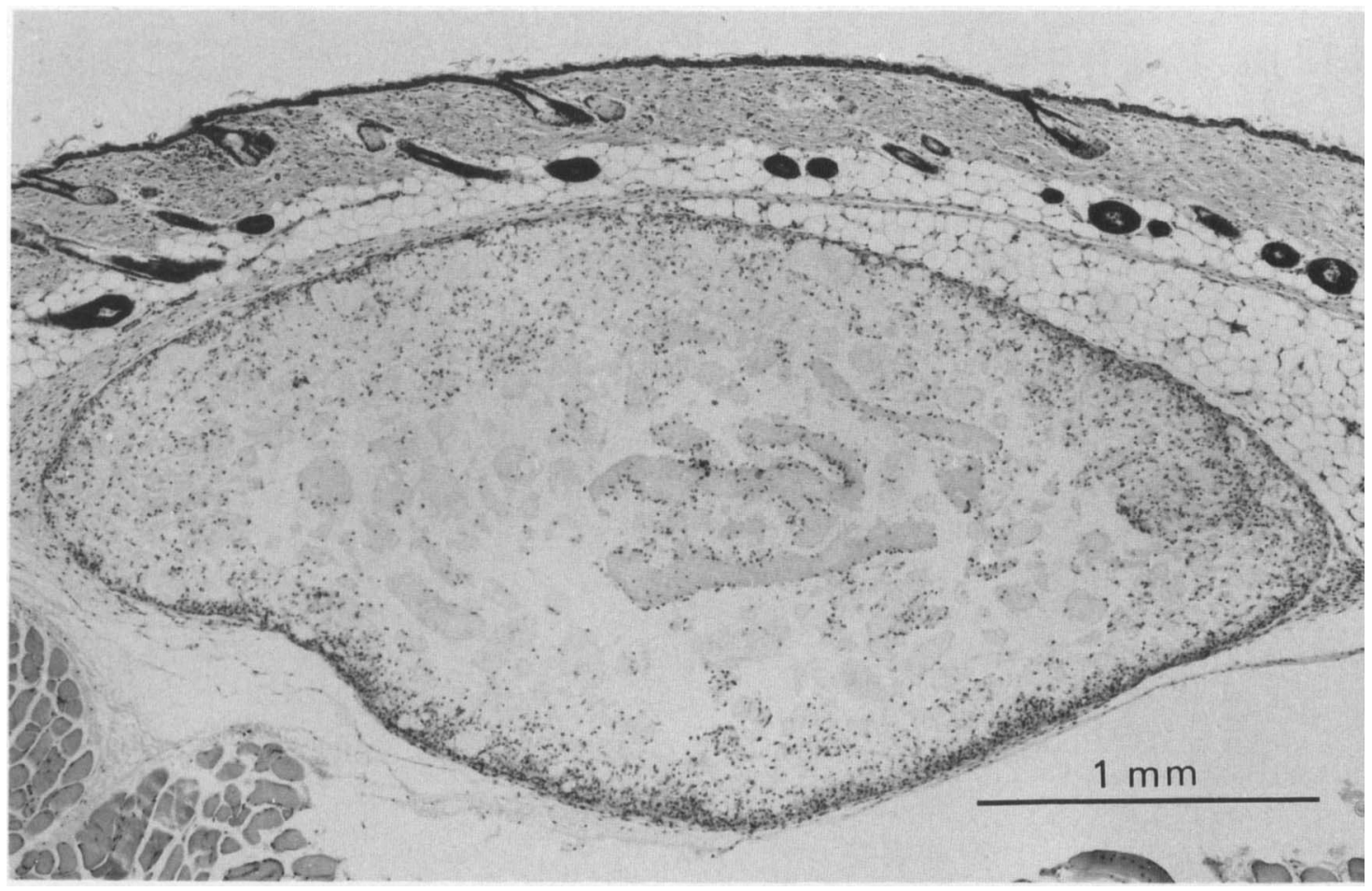

Fig. 1. Low-power photomicrograph of tissue reaction produced 8 days after subcutaneous injection of sterile semi-solid agar into the groin of an adult male mouse. A discrete collection of inoculum, surrounded and diffusely infiltrated by macrophages, is seen in the subcutaneous tissue which shows minimal evidence of an acute inflammatory reaction.

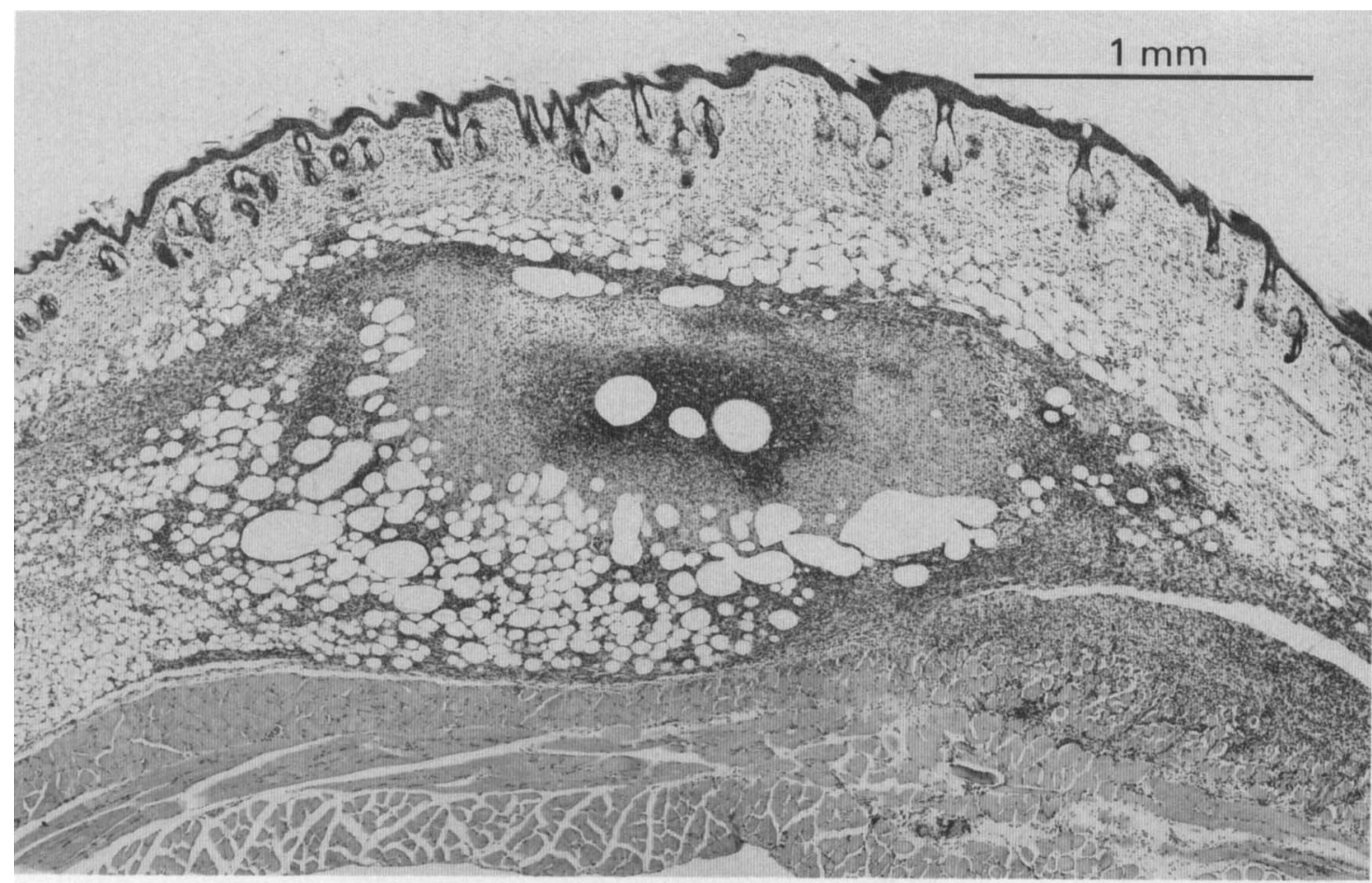

Fig. 2. Low-power photomicrograph of type-A tissue reaction produced 8 days after injection of a suspension of $B$. gingivalis into the groin of an adult male mouse. A diffuse inflammatory infiltrate, predominantly polymorphonuclear leucocytes, is present in the subcutaneous connective tissue. The overlying epithelium and underlying muscle show minimal acute inflammatory reaction. 


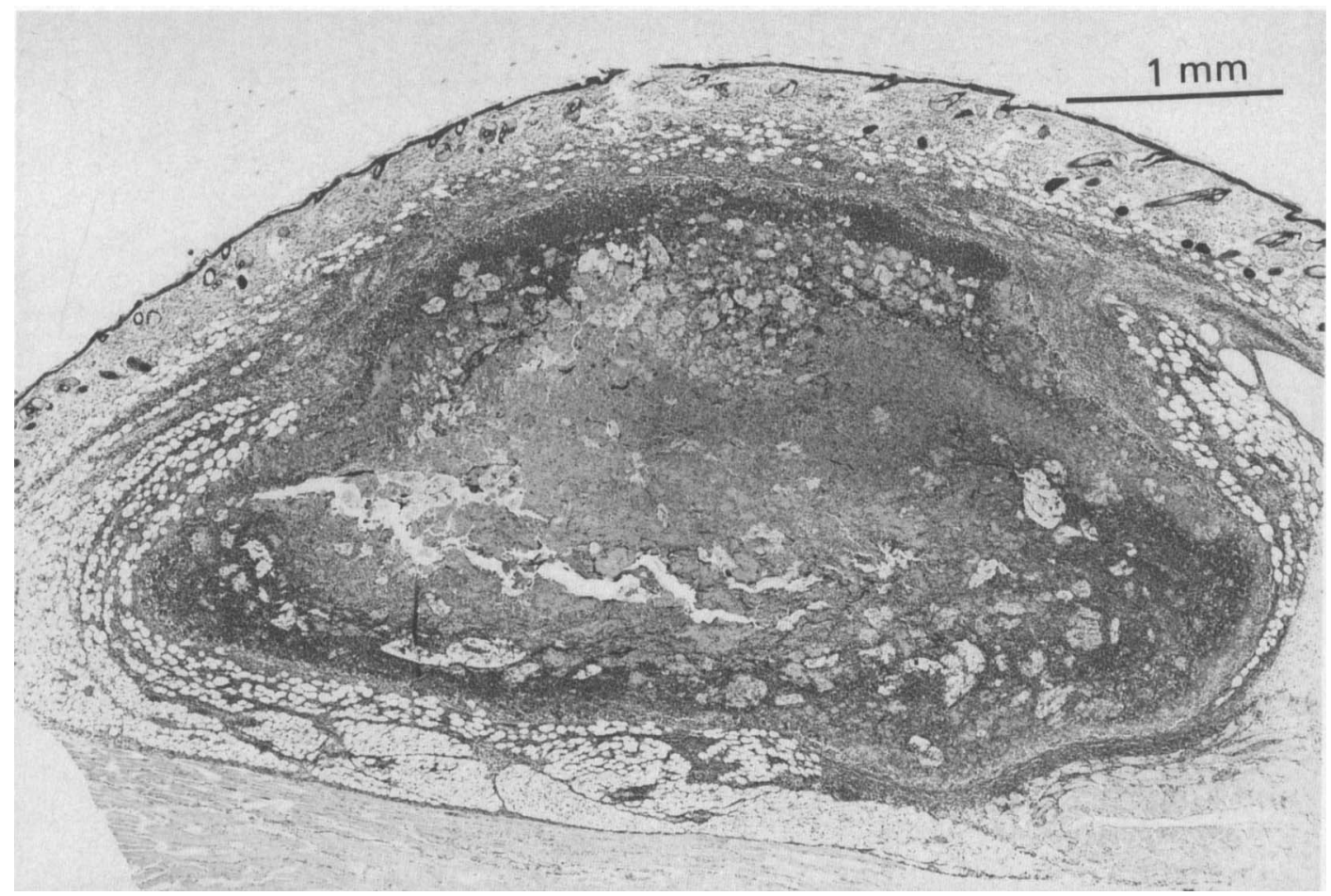

Fig. 3. Low-power photomicrograph of type-B tissue reaction produced 8 days after subcutaneous injection of a suspension of $S$. milleri into the groin of an adult male mouse. An abscess has developed with a central area of necrosis surrounded by a large number of acute inflammatory cells.

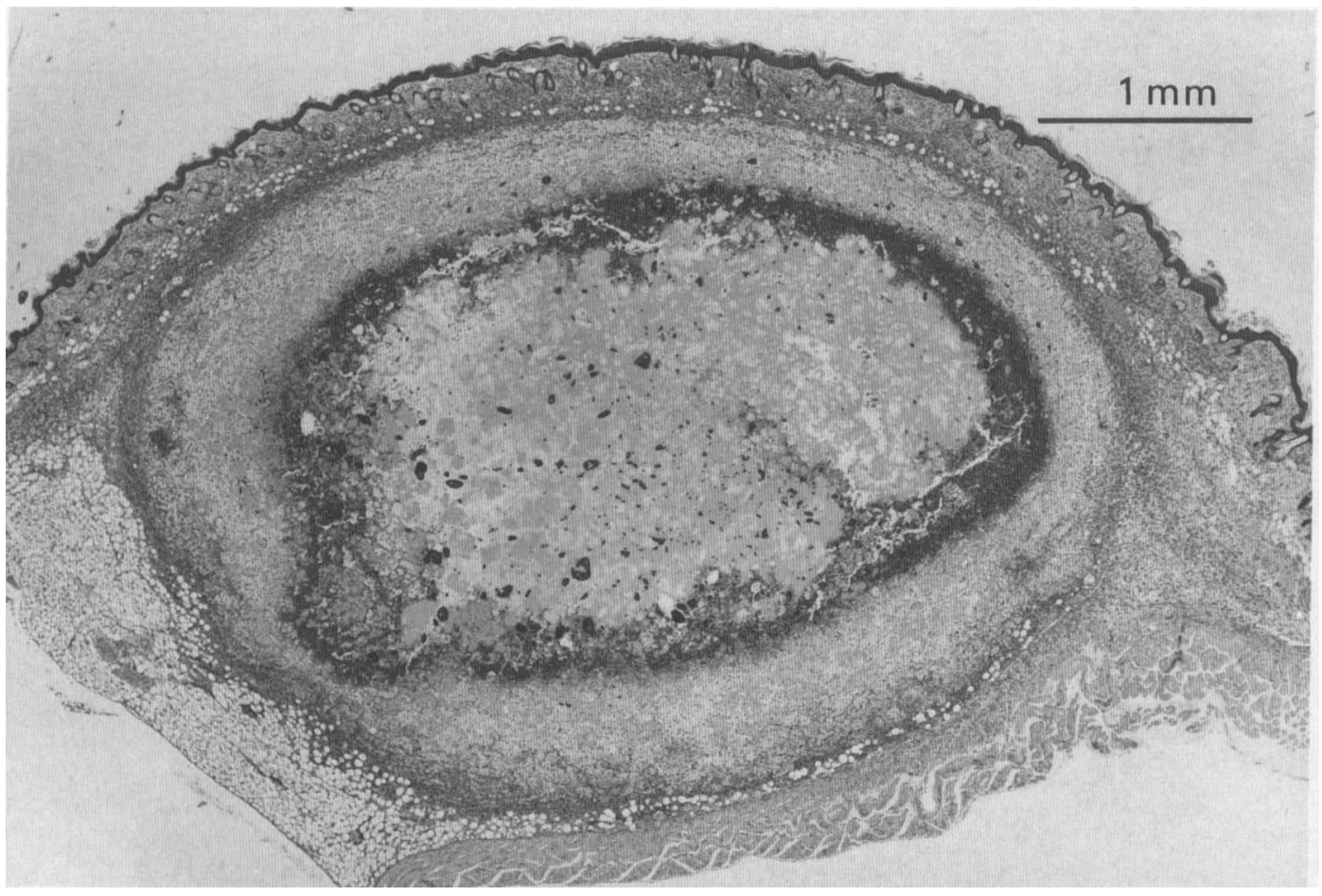

Fig. 4. Low-power photomicrograph of type-C tissue reaction produced 8 days after subcutaneous injection of a suspension of $F$. nucleatum into the groin of an adult male mouse. An abscess has developed with an area of central necrosis surrounded by three distinct bands of reaction, the middle of which consists of necrotic inflammatory cells. 
ium nucleatum and Peptostreptococcus spp. were the only ones recovered on every occasion they were used. As a group, gram-negative bacilli were recovered at high concentrations significantly more often than either $\mathrm{CO}_{2}$-dependent gram-positive cocci $(p<0.05)$ or anaerobic gram-positive cocci $(\mathrm{p}<0.001)$. There was no significant difference between the recovery of $\mathrm{CO}_{2}$-dependent grampositive cocci and that of anaerobic gram-positive cocci.

$F$. nucleatum was the only species that produced the same tissue reaction (type $C$ ) on every occasion it was tested (table II). Streptococcus milleri and Peptococcus spp. produced either type-A or type-B reactions whereas Peptostreptococcus spp. produced either type-B or type- $\mathrm{C}$ reactions. Bacteroides intermedius and $B$. ruminicola produced either typeA or type-C reactions. The other Bacteroides spp. produced each of the three tissue reactions on at least one occasion. Strains of $F$. nucleatum or $B$. intermedius produced a type- $\mathrm{C}$ reaction significantly more frequently than strains of $S$. milleri, Peptococcus spp., Peptostreptococcus spp., B. gingivalis or $B$. oralis $(\mathrm{p}<0.05)$. A type-C reaction was produced by $B$. oralis and $B$. melaninogenicus on more occasions than by $S$. milleri and Peptococcus spp. $(\mathrm{p}<0.05)$. As a group, anaerobic gram-negative bacilli elicited a type-C rather than a type-A or type-B reaction more often than $\mathrm{CO}_{2}$-dependent gram-positive cocci $(p<0.001)$ or anaerobic grampositive cocci $(\mathrm{p}<0.001)$. There was no statistical difference between the tissue reactions produced by $\mathrm{CO}_{2}$-dependent gram-positive cocci and anaerobic gram-positive cocci.

\section{Double infection experiments}

The pathogenicity of 11 different combinations of two bacterial species was assessed in a total of 55 mice. The nature of the tissue reactions produced by four of the combinations is shown in table III. The bacterial recovery and tissue reactions produced in these animals are representative of those encountered during experiments with other strains in similar bacterial group pairings. Both bacterial strains were recovered from abscesses in high concentrations statistically more often from combinations that contained an anaerobic gram-negative bacillus strain than those which did not $(\mathrm{p}<$ 0.001 ). From seven mice, only one of the two bacterial species inoculated was recovered. The bacterial species lost from the original inoculum mixture on these occasions were Peptococcus spp. ( 2 animals) and Peptostreptococcus spp. (5 animals) when combined with $S$. milleri.

Combinations containing $B$. melaninogenicus or $F$. nucleatum produced the same type of tissue reaction (type $C$ ) on every occasion. Injection of the remaining bacterial combinations produced different reactions on different occasions. Seven of the nine combinations containing anaerobic gramnegative bacilli produced a type-C reaction rather than type A or type $B$ more of ten than combinations of $\mathrm{CO}_{2}$-dependent and strictly anaerobic grampositive cocci $(\mathrm{p}<0 \cdot 05)$. The two exceptions were combinations involving $B$. intermedius with Peptococcus spp. and $B$. oralis with Peptococcus spp., which on occasions produced a type-B reaction. Bacterial combinations containing anaerobic gram-

Table II. Distribution of experimental animals according to the type of tissue reaction and the concentration of viable bacteria recovered from 81 experimental abscesses 8 days after subcutaneous inoculation with a single bacterial strain

\begin{tabular}{|c|c|c|c|c|c|c|c|}
\hline \multirow{2}{*}{$\begin{array}{l}\text { Bacterial } \\
\text { species }\end{array}$} & \multirow{2}{*}{$\begin{array}{l}\text { Number of } \\
\text { animals }\end{array}$} & \multicolumn{3}{|c|}{$\begin{array}{l}\text { Number of animals with pus } \\
\text { containing }(\mathrm{cfu} / \mathrm{ml})\end{array}$} & \multicolumn{3}{|c|}{$\begin{array}{l}\text { Number of animals with } \\
\text { tissue reaction type }\end{array}$} \\
\hline & & NG & $10^{3}$ & $10^{7}-10^{9}$ & A & B & $\mathrm{C}$ \\
\hline S. milleri & 11 & 3 & 5 & 3 & 3 & 8 & 0 \\
\hline $\begin{array}{l}\text { Peptococcus spp. } \\
\text { Peptostreptococcus spp. }\end{array}$ & $\begin{array}{r}11 \\
4\end{array}$ & $\begin{array}{l}6 \\
0\end{array}$ & $\begin{array}{l}5 \\
1\end{array}$ & $\begin{array}{l}0 \\
3\end{array}$ & $\begin{array}{l}6 \\
0\end{array}$ & $\begin{array}{l}5 \\
3\end{array}$ & $\begin{array}{l}0 \\
1\end{array}$ \\
\hline $\begin{array}{l}\text { B. oralis } \\
\text { B. melaninogenicus } \\
\text { B. intermedius } \\
\text { B. gingivalis } \\
\text { B. ruminicola } \\
\text { F. nucleatum }\end{array}$ & $\begin{array}{l}11 \\
14^{*} \\
11 \\
8 \\
4 \\
7\end{array}$ & $\begin{array}{l}5 \\
3 \\
1 \\
3 \\
2 \\
0\end{array}$ & $\begin{array}{l}1 \\
4 \\
1 \\
2 \\
0 \\
0\end{array}$ & $\begin{array}{l}5 \\
6 \\
9 \\
3 \\
2 \\
7\end{array}$ & $\begin{array}{l}3 \\
1 \\
1 \\
3 \\
2 \\
0\end{array}$ & $\begin{array}{l}4 \\
3 \\
0 \\
2 \\
0 \\
0\end{array}$ & $\begin{array}{r}4 \\
9 \\
10 \\
3 \\
2 \\
7\end{array}$ \\
\hline
\end{tabular}

$\mathrm{NG}=$ no growth

* One animal died on day 3 and is not included in results. 
Table III. Nature of experimental abscess produced in mice 8 days after subcutaneous injection of a mixture of two bacterial strains

\begin{tabular}{|c|c|c|c|c|c|c|c|}
\hline \multirow{2}{*}{$\begin{array}{l}\text { Bacterial } \\
\text { combination }\end{array}$} & \multirow{2}{*}{$\begin{array}{l}\text { Number of } \\
\text { animals }\end{array}$} & \multicolumn{3}{|c|}{$\begin{array}{l}\text { Number of aspirates containing both } \\
\text { bacterial strains (cfu/ml) }\end{array}$} & \multicolumn{3}{|c|}{$\begin{array}{l}\text { Number of animals with } \\
\text { tissue reaction type }\end{array}$} \\
\hline & & NG & $10^{3}$ & $10^{7}-10^{9}$ & A & B & $\mathrm{C}$ \\
\hline $\begin{array}{l}\text { S. milleri } \\
+ \\
\text { Peptococcus spp. }\end{array}$ & $8^{*}$ & 2 & 1 & 3 & 2 & 6 & 0 \\
\hline $\begin{array}{l}\text { S. milleri } \\
+ \\
\text { B. intermedius }\end{array}$ & 10 & 0 & 1 & 9 & 1 & 0 & 9 \\
\hline $\begin{array}{c}\text { Peptococcus spp. } \\
+ \\
\text { B. intermedius }\end{array}$ & 4 & 0 & 2 & 2 & 0 & 2 & 2 \\
\hline $\begin{array}{c}\text { Peptococcus spp. } \\
+ \\
\text { F. nucleatum }\end{array}$ & 4 & 0 & 0 & 4 & 0 & 0 & 4 \\
\hline
\end{tabular}

$\mathrm{NG}=$ no growth.

* From 2 animals only one strain was recovered.

negative bacilli produced a type- $C$ reaction rather than type A or type B statistically more frequently than combinations of $\mathrm{CO}_{2}$-dependent gram-positive cocci and anaerobic gram-positive $\operatorname{cocci}(\mathrm{p}<$ $0 \cdot 001)$.

\section{Discussion}

Early investigations, with bacteria obtained from gingival sites, demonstrated that " $B$. melaninogenicus" was essential for the development of lesions in experimental animals (MacDonald et al., 1963; Socransky and Gibbons, 1965). The present study has revealed that pure cultures of various anaerobic gram-negative bacilli, anaerobic gram-positive cocci and $\mathrm{CO}_{2}$-dependent gram-positive cocci are capable of producing infection when injected subcutaneously in mice. These findings are similar to those with strains of $B$. oralis, $B$. ruminicola, $B$. gingivalis and $B$. melaninogenicus isolated from gingival margins of teeth or necrotic dental pulps (Sundqvist et al., 1979; van Steenbergen et al., 1982; Pancholi et al., 1985) and strains of $F$. nucleatum, facultative gram-positive cocci or anaerobic gram-positive cocci isolated from non-oral sites (Brook and Walker, 1984, 1986).

The concentrations of the viable bacteria recovered from the experimental infections in this study varied. Recovery of Bacteroides spp. at concentrations of $c .10^{9}-10^{10} \mathrm{cfu} / \mathrm{ml}$ has been reported (Sundqvist et al., 1979; Pancholi et al.,
1985) which, although higher than those recorded for the strains of Bacteroides species used in the present study, may be explained partly by methodological differences. The mean recovery of $F$. nucleatum reported by Brook and Walker (1986) was $10^{7} \mathrm{cfu} / \mathrm{ml}$, a figure similar to that obtained in the present investigation. There do not appear to be any published quantitative descriptions of the recovery of facultative or strictly anaerobic grampositive cocci from experimental infections.

Variations in bacterial survival in vivo imply differences in the ability of bacterial species to evade host defence mechanisms. It appears that anaerobic gram-negative bacilli are more resistant to host defences than anaerobic gram-positive cocci or S. milleri. It has been proposed that the possession of capsular material enables Bacteroides spp. to evade phagocytosis (Okuda and Takazoe, 1973) and capsulate strains have been isolated from orofacial abscesses (Brook, 1986). Therefore, although the possession of capsular material was not assessed in the present study, capsules may have contributed to the varied pathogenic potentials of different bacterial isolates. The possession of capsular material may be lost under laboratory conditions (Ward and Berkley, 1981) and, therefore, bacterial strains which have been repeatedly subcultured over extended periods may lose their pathogenic potential.

Previous investigations have described similar tissue reactions to those seen in the present study. 
Generally, strains of $B$. melaninogenicus and $B$. intermedius have produced localised abscesses whereas $\boldsymbol{B}$. gingivalis has been associated with a spreading infection (Sundqvist et al., 1979; Kastelein et al., 1981; van Steenbergen et al., 1982; Brook et al., 1983). The division of tissue lesions into the three types of reaction seen in the present study has not previously been described. However, they would appear to be quite distinct, type $\mathrm{C}$ being the most severe. Such a classification may, therefore, help determine which bacterial species in acute dentoalveolar abscesses cause most tissue damage.

Lesions induced by combinations of bacteria tended to yield both strains at high concentrations, including those which had previously been recovered at low concentrations during single strain experiments. This was especially true for double infections involving anaerobic gram-negative bacilli. Quantitative microbiological investigation of experimental infections with mixtures of oral bacteria does not appear to have been reported previously. However, increased recovery of nonoral isolates of $F$. nucleatum and Staphylococcus aureus combined experimentally has been described (Brook and Walker, 1986). Furthermore, experimental lesions produced by combinations of bacteria have been noted to be larger than those produced by pure cultures of the same species (Brook and Walker, 1986). It has also been noted that the

\section{REFERENCES}

Brook I 1986 Isolation of capsulate anaerobic bacteria from orofacial abscesses. Journal of Medical Microbiology 22: 171-174.

Brook I, Walker R I 1984 Pathogenicity of anaerobic grampositive cocci. Infection and Immunity 45 : 320-324

Brook I, Walker R I 1986 The relationship between Fusobacterium species and other flora of mixed infection. Journal of Medical Microbiology 21 : 93-100.

Brook I, Gillmore J D, Coolbaugh J C, Walker R I 1983 Pathogenicity of encapsulated Bacteroides melaninogenicus group, $B$. oralis and $B$. ruminicola subsp. brevis in abscesses in mice. Journal of Infection 7: 218-226.

Heimdahl A, von Konow L, Satoh T, Nord C E 1985 Clinical appearance of orofacial infections of odontogenic origin in relation to microbiological findings. Journal of Clinical Microbiology 22: 299-302.

Jones G R, Gemmell C G 1986 Effects of Bacteroides asaccharolyticus cells and $B$. fragiis surface components on serum opsonisation and phagocytosis. Journal of Medical Microbiology 22: 225-229.

Kastelein P, van Steenbergen T J M, Bras J M, De Graaff J 1981 An experimentally induced phlegmonous abscess by a strain of Bacteroides gingivalis in guinea pigs and mice. Antonie van Leeuwenhoek 47: 1-9.

Lewis M A O, MacFarlane T W, McGowan D A 1986 Quantitative bacteriology of acute dento-alveolar abscesses. Journal of Medical Microbiology 21 : 101-104. presence of facultative or anaerobic gram-positive cocci exacerbates the abscesses produced by other aerobic and anaerobic bacteria (Brook and Walker, 1984). While these observations are in agreement with the general findings of the present study, the exact role and relative importance of individual organisms in the mixed flora is still not fully understood. However, anaerobic gram-negative bacilli isolated from acute dentoalveolar abscesses appear either to protect other bacteria from host defences or to provide a suitable environment for their mutual proliferation, or both, by interfering with serum opsonisation or processes of intracellular killing by phagocytes (Jones and Gemmell, 1986).

The variations in pathogenicity seen in the present study may help explain variations seen in the clinical presentation of acute dentoalveolar abscesses in man. Further work is required on these inter-relationships in the mixed microbial flora of acute dentoalveolar abscesses and the mechanisms by which bacterial species resist host defences.

This work was supported by Bencard, Brentford, Middlesex. We gratefully acknowledge the technical assistance of $D$. MacKenzie (Oral Microbiology Unit), W. Marshall (Oral Pathology Unit) and F. Darling (Department of Bacteriology and Immunology) University of Glasgow.

MacDonald J B, Socransky S S, Gibbons R J 1963 Aspects of the pathogenesis of mixed anaerobic infections of mucous membranes. Journal of Dental Research 42 Suppl. 1: 529544.

Okuda K, Takazoe I 1973 Antiphagocytic effects of the capsular structure of a pathogenic strain of Bacteroides melaninogenicus. Bulletin of Tokyo Dental College 14: 99-104.

Pancholi V, Ayyagari A S, Agarwal K C 1985 Experimentally induced subcutaneous infection by black-pigmented Bacteroides species in rats. Journal of Infection 11 : 131-137.

Socransky S S 1977 Microbiology of periodontal diseasepresent status and future considerations. Journal of Periodontology 48: 497-504.

Socransky S S, Gibbons R J 1965 Required role of Bacteroides melaninogenicus in mixed anaerobic infections. Journal of Infectious Diseases 115 : 247-253.

Sundqvist G K, Eckerbom M I, Larson A P, Sjögren U T 1979 Capacity of anaerobic bacteria from nectrotic dental pulps to induce purulent infections. Infection and Immunity 25 : 685-693.

Takazoe I, Nakamura T 1971 Experimental mixed infection by human gingival crevice material. Bulletin of Tokyo Dental College 12: 85-93.

van der Velden U, van Winkelhoff A J, Abbas F, De Graaff J 1986 The habitat of periodontopathic microorganisms. Journal of Clinical Periodontology 13: 243-248.

van Steenbergen $\mathbf{T} \mathbf{J}$ M, Kastelein P, Touw J J A, De Graaff J 1982 Virulence of black-pigmented Bacteroides strains from periodontal pockets and other sites in experimentally 
induced skin lesions in mice. Journal of Periodontal Research 17: 41-49.

van Steenbergen T J M, van Winkelhoff A J, De Graaff J 1984

Pathogenic synergy: mixed infections in the oral cavity. Antonie van Leeuwenhoek 50: 789-798.

Ward J B, Berkeley R C W 1981 The microbial cell surface and adhesion. In: Berkeley R C W et al. (eds) Microbial adhesion to surfaces. Ellis Horwood Limited, Chichester, pp 47-66.

Williams B L, McCann G F, Schoenknecht F D 1983 Bacteriology of dental abscesses of endodontic origin. Journal of Clinical Microbiology 18: 770-774. 